Nicole Torka, Ivy Goedegebure*

\title{
Perceived distributive justice and Leader-Member Exchange: An exploration among Dutch and Polish (agency) workers
}

\begin{abstract}
We compare the distributive justice perceptions of agency workers and permanent staff concerning different aspects of HRM. Moreover, we investigate if the supervisor-subordinate relationship quality (Leader-Member Exchange, LMX) influences the relationship between the contract status and distributive justice perceptions. We conducted semi-structured interviews in three Dutch logistics companies and distributed questionnaires among workers performing low-skilled jobs. Results show that a direct relationship between contract status and distributive justice perceptions remains when testing the mediator effect of LMX. Contract status seems partly to determine perceived LMX and, consequently, perceived distributive justice. However, the differences in perceived justice concerning voice, participation and pay between the worker groups change when individual workers perceive high-quality LMX. Thus, not only between group differences might be relevant, but also within group differences.
\end{abstract}

\section{Wahrgenommene Verteilungsgerechtigkeit und Leader-Member Exchange: Eine Exploration unter niederländischen und polnischen (Leih)Arbeitern}

\section{Zusammenfassung}

Wir vergleichen die wahrgenommene Verteilungsgerechtigkeit bei Festangestellten und Leiharbeitnehmern hinsichtlich verschiedener Aspekte des HRM. Es wird untersucht, ob die Qualität der Vorgesetzten-Mitarbeiter-Beziehung (Leader-Member Exchange, LMX) die Beziehung zwischen Vertragsstatus und wahrgenommener Verteilungsgerechtigkeit wie vermutet beeinflusst. Wir haben teilstrukturierte Interviews in drei niederländischen Logistikunternehmen erhoben und Arbeitskräfte in gering qualifizierter Beschäftigung mit einem Fragebogen befragt. Die Ergebnisse zeigen, dass die Beziehung zwischen Vertragsstatus und wahrgenommener Verteilungsgerechtigkeit beim Test des Mediator-Effekts von LMX bestehen bleibt. Der Vertragsstatus scheint die Wahrnehmung des LMX und

* Dr. Nicole Torka (corresponding author), Twente School of Management (TSM), Enschede/The Netherlands. E-mail: nicoletorka@gmail.com.

Drs. Ivy Goedegebure, Saxion University of Applied Sciences, The Netherlands.

** The authors would like to thank mr. drs. Suzanne Hidajat - Engelsman and the reviewers for their contributions for making this article possible.

Artikel eingegangen: 21.1.2013

revidierte Fassung akzeptiert nach doppelt-blindem Begutachtungsverfahren: 26.9.2016. 
folglich das Gerechtigkeitsempfinden (teilweise) zu determinieren. Es ändern sich die Unterschiede im Gerechtigkeitsgefühl hinsichtlich der Mitsprache, der Mitbestimmung und des Gehalts zwischen den Gruppen, wenn individuelle Arbeitskräfte eine hohe LMX Qualität wahrnehmen. D.h. es sind Unterschiede zwischen Gruppen und auch innerhalb von Gruppen zu beachten.

Key words: (Polish) temp agency workers, perceived distributive justice, LMX, voice, participation (JEL: L2, M5, Y8)

\section{Introduction}

Many studies show that, compared to permanent staff, agency workers perceive and receive unequal treatment (e.g. Brinkmann \& Nachtwey, 2014; Helfen et al., 2015; Nienhüser \& Matiaske, 2006) as well as experience other occupational disadvantages (e.g., risk of losing skills; see, for example, Dütsch \& Struck, 2014). Policy makers and scholars have recognised this inequality issue seems to differ across European countries and pointed to inequalities in legislation as one of the main causes. Consequently, the European Union has sought to harmonise the law across European Union member states, enacting the Agency Work Directive (2008/104/EC). The aim of this legislation is to guarantee agency workers equal rights, compared to permanent staff in the same business who do the same job, on basic working and employment conditions (e.g., pay, working time, holidays, pregnancy leave). However, the Directive only concerns basic conditions and excludes many other areas of Human Resource Management (HRM) such as the job content, voice and development opportunities. Thus, even after implementing the Directive, opportunities for agencies and user firms remain for treating agency workers unequally.

Research within organisations about agency workers justice perceptions is still in demand (e.g. Connelly \& Gallagher, 2004; Coyle-Shapiro et al., 2006; Holm et al., 2016; Giunchi et al., 2015; Giunchi et al., 2016). This article contributes to filling this knowledge gap by comparing the distributive justice perceptions of agency workers and permanent staff concerning different aspects of HRM (i.e., pay, physical working conditions, job content, information, voice, direct participation, development opportunities) in three user firms from the Dutch logistics industry.

Moreover, we investigate if the supervisor-subordinate relationship quality (LeaderMember Exchange [LMX], e.g. Graen et al., 1982a, 1982b; Graen \& Schiemann, 1978) influences the supposed relationship between the contract status (i.e., agency vs. permanent workers) and distributive justice perceptions. To date, LMX has still been largely neglected as an experience that might play a role in this relationship and in agency work research in general (for an exception see Flickinger et al., 2016). This is surprising since research shows that top management delegates operational HRM to direct supervisors (e.g. Perry \& Kulik, 2008; Purcell \& Hutchinson, 2007) and LMX strongly determines HRM quality and justice as perceived by workers (e.g. Andrews \& Kacmar, 2001; Graen \& Cashman, 1975; Lee, 2001; Scandura, 1999; Yukl \& Fu, 1999). Moreover, the social exchange between the individual and his or her supervisor refers to interactional justice (e.g. Cropanzano et al., 2002) and interactional justice has a strong positive influence on distributive justice perceptions (e.g. Colquitt et al., 2001). 
This paper adds even more to previous studies since our data set contains information on Dutch and Polish agency workers. Therefore, it is possible to report on distributive justice perceptions related to agency workers origin. Moreover, we can investigate if LMX interferes in this relationship. In the Netherlands, people with a Polish nationality are by far the largest group among the so-called 'flexmigrants': agency workers who have been recruited outside the Netherlands. 87.4 percent of all flexmigrants are of Polish origin (van Baars, 2014). According to the ABU (2016), the largest Dutch agency work employer association, flexmigrants are vital for the Dutch economy and especially for industries with domestic labour shortages such as food, horticulture and logistics. Despite this economic importance, work migrants and in particular those from Central Europe frequently seem to face discrimination in the Netherlands (Gijsberts \& Lubbers, 2015).

To gain insight into HRM offered to the workers and test our hypotheses we conducted 12 semi-structured interviews in three logistics companies and distributed questionnaires among workers performing low-skilled jobs. 241 respondents participated in the survey: 109 Dutch permanent employees, 65 Dutch agency workers, and 67 Polish agency workers.

This article is structured as follows. First, we present our theoretical framework and the hypotheses. After a discussion of the methodology deployed, we present the research findings. Finally, we discuss the results and limitations as well as sketch implications for research and practice.

\section{A theoretical endeavour}

Empirical studies show that if workers experience justice from their work organisation their attitudes improve (e.g., satisfaction, commitment) and, consequently, their performance (e.g. Colquitt et al., 2001; Cohen-Carash \& Spector, 2001; Daileyl \& Kirk, 1992; Meyer et al., 2002). Based on the work of authors such as Adams (1963, 1965), Cropanzano and Folger (1991), Greenberg (1990), and Thibaut and Walker (1974), Colquitt (2001) presented a four-component model of organisational justice, distinguishing between distributive, procedural, interpersonal, and informational justice. For reasons presented below, we decided to focus on distributive justice as dependent variable, but, as we showed in the introduction, interactional justice (i.e., interpersonal and informational justice) plays also an important role since we take LMX into account (see explanation for hypotheses 3 and 4).

Distributive justice generally refers to the individual's perception of fair outcomes (Adams, 1963, 1965; Greenberg, 1990) such as pay and career decisions. People compare their rewards, costs and investments with those of comparable others. They psychologically evaluate everything of personal value in relation to their inputs (e.g. education, tenure and performance) and compare this relation of input and output to those of other people. Thus, agency workers will normally perceive distributive injustice if they believe comparable others - permanent employees and/or agency workers in the same business who do the same job - receive better HRM outcomes for an equal or lesser input, or equal HRM outcomes for less or more input.

We focus on distributive justice because the EU Agency Work Directive aims to abolish the discrimination of agency workers concerning outcomes. Also, current Dutch regulations (i.e., labour law and collective agreements between agency associations and unions) aim to reduce outcome inequality concerning basic working and employment conditions be- 
tween agency workers and permanent staff. However, distributive justice concerns more than basic conditions, and this means agencies and user companies can still treat agency workers differently from permanent employees concerning other aspects of HRM such as the job content and training opportunities. Given these facts and the mentioned results of empirical studies that show agency workers perceive less fair treatment than permanent staff (e.g. Brinkmann \& Nachtwey, 2014; Helfen et al., 2015; Nienhüser \& Matiaske, 2006), we can formulate our first general hypothesis as follows:

H1: Agency workers perceive less distributive justice concerning different aspects of HRM than permanent employees.

Research shows that the length of stay or 'tenure' with the agency and the user firm has a positive influence on the HRM quality as perceived by agency workers' (e.g. Torka, 2003; Garcia-Serrano, 2004). Moreover, tenure plays an important role in Dutch regulations on temp agency work. Dutch regulations make a difference between phase A, B and C temp agency contracts. While in phase $\mathrm{C}$ agency workers have a permanent contract with the temp agency, the rights of agency workers in phase A (an agency tenure of less than 78 weeks) and B are limited. For example, in phase A, when the worker is sick or the customer ceases the assignment the contract ends. Therefore, it is important to control for tenure when investigating possible differences between agency workers and permanent staff.

The tenure issue shows that agency workers - like permanent staff - cannot be perceived as a homogenous group and this is also true for other differences: They differ concerning their preferences, individual characteristics, skills and so on (e.g. De Cuyper et al., 2008; Guest, 2004). Thus, agency workers' origin or, more precisely, their differential treatment because of their origin, might also explain differences in justice perceptions among agency workers and between agency workers and permanent staff. Concerning one issue flexmigrants seem not to receive different treatment than local agency workers in the Netherlands: The aforementioned phase of the temp agency contracts. 70.8 percent of the flexmigrants are subject to a phase $\mathrm{A}$ contract (phase $\mathrm{B}=23.8 \%$; phase $\mathrm{C}=5.4 \%$ ) (van Baars, 2014) compared to 85.7 percent of all agency workers (phase $\mathrm{B}=11.7 \%$; phase $\mathrm{C}=$ $2.6 \%$ ) (Vermeulen et al., 2014). Thus, the majority of agency workers - and independent of origin - fall into the 'unprivileged' short-term category. Compared to all agency workers, it is unclear why relatively fewer flexmigrants (mean difference is about 15\%) fall into this category.

However, further evidence shows that the position of work migrants and especially those from Central Europe might is more vulnerable than those of local agency workers. Work migrants who work for a temp agency might have to bear a double burden: compared to permanent staff, but alike local agency workers, they might perceive unequal treatment because of their contract status but, in contrast to local agency workers, additionally also because of their origin. After all, (flex)migrants frequently seem to face discrimination in the Netherlands. Recent research shows that in the Netherlands Polish people perceive an increase in group discrimination: While in 2010/2011 39 percent perceived discrimination of their origin group (i.e., group discrimination) 'very frequently', in 2012/2013 49 percent did so. Altogether, in the Netherlands 84 percent of the Polish people perceive discrimination of their origin group 'frequently' or 'very frequently' including labour market discrim- 
ination (Gijsberts \& Lubbers, 2015). Moreover, a very recent study shows that compared to Germany, Ireland and the UK, Polish migrants perceive the most group discrimination in the Netherlands (McGinnity \& Gijsberts, 2016).

In the Netherlands, as well as in many other countries, discrimination among agency workers is officially prohibited. Thus, it is not allowed to offer equal agency workers unequal conditions because of, for example, differences in gender, race, age, and nationality. However, as mentioned before, current and future regulations preserve space for agencies and user firms to treat agency workers differently than permanent employees and among each other on issues beyond the basic conditions. Therefore, organisations still have 'legal space' to discriminate against migrant workers. As the above-mentioned studies show Polish people perceive increasing group discrimination in the Netherlands. Thus, it appears there is no warrant for assuming that Polish agency workers perceive treatment equal to those of Dutch agency workers. Moreover, it can be argued that work migrants might have relatively higher expectations concerning monetary rewards than local agency workers: After all, they might make higher sacrifices (for example, leaving their home country and family [temporarily]) and have higher living costs (for example, housing in the Netherlands and abroad) than their local agency workers. Therefore, we formulate hypothesis 2 as follows:

H2: $\quad$ Polish agency workers perceive less distributive justice concerning different aspects of HRM than Dutch agency workers.

Although hypotheses 1 and 2 are based on evidence, for two reasons it is too simplistic to assume a direct relationship between contract status (here, agency vs. permanent workers) as well as agency workers origin (here, Dutch vs. Polish origin) and perceived organisational justice: (1) Some user firms seem to treat agency workers as their 'own' permanent staff and, related to the former, such an assumption (2) ignores potential diversity in management behaviour (e.g. McDonald \& Makin, 2000; Pearce, 1993; Torka \& Schyns, 2010). In general, research shows that direct supervisors can strongly determine the working conditions of their subordinates (e.g. Perry \& Kulik, 2008; Purcell \& Hutchinson, 2007), and differences in the quality of the direct supervisor-subordinate relationship can explain inequalities in (perceived) working conditions among subordinates who share the same supervisor (e.g. Andrews \& Kacmar, 2001; Lee, 2001; Piccolo et al., 2008; Scandura, 1999). Thus, differences in supervisor-subordinate relationship quality between and among permanent staff and agency workers might determine dissimilarities in distributive justice perceptions.

Again, with reference to evidence that agency workers and especially flexmigrants receive less fair treatment than permanent staff, one might argue the contract status and the origin directly determine the supervisor-subordinate relationship, and through this distributive justice. In other words, the agency workers' relationship with their supervisor suffers, because they are agency workers and this holds and is even more true when they are migrant workers. Thus, compared to permanent staff, the lower relationship quality explains (perceived) distributive injustice.

Given these arguments and reflections, we decided to investigate how the supervisorsubordinate relationship quality influences the contract status and distributive justice link as well as the agency workers origin and distributive justice link. The concept we focus on is 
Leader-Member Exchange (LMX; e.g. Graen et al., 1982a, 1982b; Graen \& Schiemann, 1978) as it describes this relationship quality and also has been shown to be related to workers' justice perceptions (e.g. Andrews \& Kacmar, 2001; Lee, 2001; Piccolo et al., 2008; Scandura, 1999). Moreover, as mentioned in the introduction, the social exchange between the individual and his or her supervisor refers to interactional justice (e.g. Cropanzano et al., 2002) and interactional justice has a strong positive influence on distributive justice (e.g. Colquitt et al., 2001).

The second reason for including this construct is the fundamental premise of LMX theory, namely, that supervisors have different relationships with each of their subordinates (e.g. Graen \& Uhl-Bien, 1995). Thus, rather than assuming that different worker groups such as permanent and agency workers or local agency workers and flexmigrants have a different relationship quality with their supervisor per se (i.e., simply because of their group membership), LMX researchers argue one needs to recognise and take into account individualised relationships of each follower with their leader. Consequently, we cannot assume agency workers or flexmigrants as groups have low-quality relationships with their supervisor or that permanent employees have high-quality relationships with their supervisor (Danserau et al., 1975). Rather, following this skeptical line of reasoning, we assume that LMX might not depend on the contract status or classification as flexmigrant, but rather is an individualised phenomenon that changes or moderates the contract status as well as the origin and distributive justice connection.

However, since research about the influence of LMX on the connection between contract status as well as agency workers origin and distributive justice is lacking, we decided to test two hypotheses. Hypothesis 3 supports the idea that the contract status and the agency workers origin are decisive for LMX: The supervisor-subordinate relationship quality is less good for both groups of agency workers (locals and flexmigrants) than for permanent employees and, consequently, the former perceive less distributive justice than the latter. Hypotheses 4 is in line with LMX theory and assumes that group membership (i.e., agency workers vs. permanent employees and local agency workers vs. flexmigrants) is itself insufficient for LMX and, consequently, distributive justice.

H3: LMX mediates the relationship between contract status as well as agency workers' origin and distributive justice concerning different aspects of HRM.

H4: LMX moderates the relationship between contract status as well as agency workers' origin and distributive justice concerning different aspects of HRM.

\section{Method}

\section{Procedure}

We decided to conduct our research in the Dutch logistics industry, because this industry is a heavy user of agency workers. The largest group of flexmigrants (30\%) work in logistics (Van Baars, 2014). We contacted the business manager of logistics of a member organisation of the largest association of Dutch employment agencies. We requested and were granted access to user firms that also use agency workers from Central European countries. 
Finally, three logistics companies, each having over 100 employees, agreed to participate in the research. To gain insight into differences and similarities in HRM for agency workers and permanent workers as well as for local agency workers and Polish agency workers, we conducted 12 lengthy semi-structured pilot interviews, including the HR manager, a direct supervisor, an agency worker, and a permanent employee in each company. We asked questions about similarities and differences between the respective worker groups, focusing on the following aspects of HRM: pay, physical and social working conditions, job content, information, voice, participation, and development opportunities. To test our hypotheses, we then conducted questionnaire research in the three companies among workers performing low-skilled jobs (i.e., jobs without requirements for formal education/training). The questionnaire was also translated into Polish.

\section{Participants}

241 respondents participated in the research: 109 Dutch permanent workers, 65 Dutch agency workers, and 67 Polish agency workers. The overall response rate was 33 percent. In company 1 , the response rate was the highest: 50.2 percent compared to just 18.7 percent in company 2 and 31.1 percent in company 3 . The large differences in response rate can be explained by the differences in research support from user firm managers. In company 1, management was most supportive: in contrast to company 2 and 3, management invited the researcher to return several times to collect data.

The Polish agency workers (Kruskal-Wallis test: mean rank $=79.21 ; \mathrm{df}=2 ; \mathrm{p}=.00$ ) are significantly younger (median $=<25$ years) than the Dutch agency workers (mean rank $=$ 114.95; median $=25-35$ years), which, on their turn, are significantly younger than the Dutch permanent workers (mean rank $=150.30$; median $=35-45$ years). More than 55 percent of the Polish agency workers are younger than 25 years of age. In contrast, 13.8 percent of the permanent workers fall into this age category. In addition, 49.5 percent of the Dutch permanent workers, 32.3 percent of the Dutch agency workers and 9 percent of the Polish agency workers are older than 35 years of age. Besides that, the distribution of gender differs between the three groups $\left(\mathrm{chi}^{2}=15.665 ; \mathrm{df}=2 ; \mathrm{p}=.00\right) .31 .3$ percent of the Polish agency workers are female; in contrast to 16.9 percent of Dutch agency workers and 8.3 percent of Dutch permanent workers.

In general, 46.2 percent of the agency workers work for less than six months for the user firms, 15.9 percent between six months and less than a year, 31.8 percent between one year and less than three years and 6 percent for more than three years. The average duration of work is nine months. However, in contrast, 62.7 percent of the Polish agency workers work for less than 6 months for the user firms. The mean difference is significant at the 0.05 level. Finally, more than 70 percent of the agency workers, both Polish and Dutch, prefer a contract with the user firm over an agency contract.

\section{Instruments}

Distributive justice. Karregat and Steensma (2005) developed an overall measure for distributive justice including aspects of pay, physical working conditions, job content, information, development opportunities, and amount of team meetings. We used their work as 
starting point, but decided to design our own scale because their measurement does not (a) differentiate between raising voice and direct influence in decision-making (participation) and (b) several important distributive justice aspects were measured with only one or two items (i.e. pay, job content, information). We measured only one aspect of distributive justice (i.e. physical working conditions) with just one item (compared to ..., my physical working conditions are ...). For distributive justice concerning pay, job content, information, voice, participation and development opportunities, we designed Likert scales with more than one item measurements. Reliability analyses show sufficient internal consistency: for pay (2 items) $\alpha=.78$, job content (9 items) $\alpha=.90$, information ( 3 items) $\alpha=.87$, voice (3 items) $\alpha=.85$, direct participation ( 3 items) $\alpha=.91$ and development (5 items) $\alpha=$ .91 (see Appendix 1 for items and PCA Eigenvalues $(\lambda)$ of the six factors; we used indices for the dependent variables). We asked the agency workers to compare themselves with permanent employees and permanent employees to compare themselves with agency workers on a five-point Likert scale $(1=$ much worse; to $5=$ much better $)$ on all the single items.

Leader-Member Exchange (LMX). Leader-member exchange (LMX) was assessed using a Dutch and a Polish translation of the 12-item scale LMX MDM developed by Liden and Maslyn (1998). Sample items include "I like my supervisor very much as a person" and "I do work for my supervisor that goes beyond what is specified in my job description". Responses were recorded on a five-point scale from $1=$ totally disagree to $5=$ totally agree. The internal consistency for the overall assessment of LMX was $\alpha=.91$.

We ascertained the contract status by asking the respondents if they had a permanent contract with the firm under investigation or were agency workers. Moreover, we asked the respondents about their origin, gender, age, contract preference (agency or user firm contract) and tenure user firm.

\section{Analytic strategy}

We conducted analyses of covariance (One-way ANCOVA) to determine a statistically significant difference between agency workers and permanent workers (hypothesis 1) and between Polish agency workers and Dutch agency workers (hypothesis 2) on distributive justice, controlling for potentially influencing background variables: We controlled for gender, age, contract preference (user firm contract) and tenure user firm. We checked for ANCOVA assumptions as normal distribution, homogeneity of variances (Levene's test), homogeneity of regressions slopes (via pre-testing significance of the interaction term in ANCOVA) and linearity of the regression. The latter is checked via Cramér's V and Spearman's correlation, for all groups, before conducting the ANCOVA. This showed that age, gender and contract preference are no relevant covariates. The assumption of independency (Keppel \& Wickens, 2004) failed for tenure. However, the independent variable is an observed variable and not a manipulated randomly assigned variable. Thus, it is an observable fact that the independent variable has a linear relation with the covariate which has not been created by the researchers. Tenure does not affect whether an employee is Polish or not nor works for an agency. Therefore the assumption of independence between the independent variable and the covariate is less relevant in this case. In the ANCOVA analyses job tenure is included as covariate. 
To test hypotheses 3 and 4 we performed regression analyses. Given our interest in the role of LMX in the contract status and distributive justice link as well as the agency workers origin and distributive justice link (hypotheses 3 and 4), we designed two dummy variables: D1 and D2. D1 represents the Dutch agency workers and D2 the group permanent workers. If D1 and D2 are disregarded (both are 0) the group Polish workers comes into view (Polish agency workers $=0 / 0$; Dutch agency workers $=1 / 0$; permanent workers $=$ $0 / 1)$. Thus, the reference category are the Polish agency workers. These dummy variables are useful because they enable the use of a single regression equation to represent the three groups. In model 1, because of the significant differences in perceived distributive justice between the groups (i.e., Polish agency workers, Dutch agency workers en permanent workers), we included job tenure as a control variable. The two dummies D1 and D2 were included in model two; in model 3 we included LMX, and in model 4 the two interactions terms were included. In addition, we conducted the mediation analysis following the four steps recommended by Baron and Kenney (1986). Moreover, we conducted Sobel-tests (Preacher \& Hayes, 2004) in the fourth step to examine the significance of the mediation.

\section{Interview findings: HRM for agency workers and permanent employees}

In all companies, agency workers seem to receive less pay than permanent employees. This can be explained by 'strictly observing' former Dutch formal regulations: it was permissible to pay agency workers who work for less than 26 weeks for the same agency and user firm less than user firms pay permanent employees. Since 30th March 2015, from day one of their assignment, agency workers receive the same salary as user firms permanent staff. It should be noted our research was conducted before this date. As mentioned before, 46.2 percent of all agency workers and 62.7 percent of the Polish agency workers work for the user firm for less than a half year. Moreover, it seems most agency workers perform less complex tasks than permanent staff, and this difference in complexity might also explains pay disparities.

Company 3 offers all agency workers training-on-the-job, but in company 1 and 2 this is reserved for permanent staff and agency workers with the prospect for a permanent contract with the user firm. According to all three HR managers, agency workers generally have to work at least one year for the user firm before they are offered a permanent contract. Moreover, the managers emphasize that while 'good' Polish agency workers could get a permanent labour contract, these workers normally do not want such long-term involvement. This is in sharp contrast to our finding that 71.6 percent of the Polish agency workers prefers a contract with the user firm.

Concerning physical and social working conditions, the overall picture is that the user firms try to minimize the differences in treatment for agency workers and permanent workers. According to the interviewees, most Polish agency workers - due to their very weak acquisition of Dutch - seem to be less socially integrated than local agency workers. However, company 1 does decidedly invest in promoting social integration by different initiatives to decrease the distance between Dutch and Polish workers. Information posters about Poland written in Dutch and about the Netherlands written in Polish can be seen all over the workplace. Furthermore, posters with translations of commonly used words in both languages are visible. 
Table 1:HR practices for agency and permanent workers in the three Dutch logistics companies

\begin{tabular}{|c|c|c|c|}
\hline $\begin{array}{l}\text { HR practice- } \\
\text { Company }\end{array}$ & Company 1 & Company 2 & Company 3 \\
\hline Job content & \multicolumn{2}{|c|}{$\begin{array}{l}\text { Only agency workers with prospect for standard employment } \\
\text { perform more complex tasks }\end{array}$} & $\begin{array}{l}\text { More challenging tasks also } \\
\text { for agency workers without } \\
\text { prospect for standard em- } \\
\text { ployment }\end{array}$ \\
\hline $\begin{array}{l}\text { Development } \\
\text { opportunities }\end{array}$ & \multicolumn{2}{|c|}{$\begin{array}{l}\text { Training-on-the-job only for agency workers with prospect for } \\
\text { standard employment }\end{array}$} & $\begin{array}{l}\text { Training-on-the-job also for } \\
\text { agency workers without pro- } \\
\text { spect for standard employ- } \\
\text { ment. Only permanent staff } \\
\text { can follow a personal devel- } \\
\text { opment trajectory }\end{array}$ \\
\hline $\begin{array}{l}\text { Physical working } \\
\text { conditions }\end{array}$ & \multicolumn{3}{|c|}{ The same for agency and permanent workers } \\
\hline $\begin{array}{l}\text { Social working } \\
\text { conditions }\end{array}$ & \multicolumn{3}{|c|}{ Local agency workers are well integrated; Polish less because of language problems } \\
\hline Pay & \multicolumn{3}{|c|}{ Agency workers receive less pay than permanent employees } \\
\hline $\begin{array}{l}\text { Information, Voice } \\
\text { and } \\
\text { Direct participation }\end{array}$ & $\begin{array}{l}\text { Only agency workers with pro- } \\
\text { spect for standard employment } \\
\text { attend team meetings together } \\
\text { with permanent staff. Other local } \\
\text { agency workers have their own } \\
\text { meetings. Polish workers have a } \\
\text { weekly meeting with their coor- } \\
\text { dinator. }\end{array}$ & $\begin{array}{l}\text { Local agency and permanent } \\
\text { workers attend meetings to- } \\
\text { gether, agency employee } \\
\text { proficient in Polish attends } \\
\text { these meetings on behalf of } \\
\text { the Polish workers. }\end{array}$ & $\begin{array}{l}\text { Agency and permanent work- } \\
\text { ers attend meetings together. }\end{array}$ \\
\hline
\end{tabular}

Concerning information equality, company 1 is the only user firm that translates the news bulletin into Polish. The company also employs three coordinators for the Polish agency workers, all of whom are fluent in the language pair. They are an important link in the agency worker, user firm and agency relationship as well as for voice and direct participation opportunities. Company 1 has had the longest experience with Polish agency workers, which may explain why they seem to have a more sophisticated approach towards these workers than either company 2 or 3 . In this context, it is somewhat surprising that, in contrast to company 2 and 3 , in company 1 it is only agency workers with a the prospect for a permanent contract with the user firm who attend team meetings together with permanent employees.

\section{Questionnaire research findings}

The interview results show that the participating companies differ concerning several HRM aspects (i.e. job content, development opportunities, information, voice, and direct participation). Therefore, we tested if it is appropriate to do a cross-case analysis with the measure 
of association $\eta^{2}$ : Between group variability divided by total variability, which is comparable to the intraclass correlation coefficient (e.g. Bickel, 2007; Snijders \& Bosker, 1999). The ANOVA tests indicated it was acceptable to pool the data. Distributive justice concerning information $\left(\eta^{2}=.006\right)$, direct participation $\left(\eta^{2}=.002\right)$, development opportunities $\left(\eta^{2}\right.$ $=.004)$, and job characteristics $\left(\eta^{2}=.006\right)$, showed all $\mathrm{F}<1$. In addition, distributive justice concerning physical working conditions $\left(\eta^{2}=.012 ; \mathrm{F}(2,235)=1.45, \mathrm{p}=.237\right)$, voice $\left(\eta^{2}=.013 ; \mathrm{F}(2,236)=1.53, \mathrm{p}=.219\right)$, and pay $\left(\eta^{2}=.009 ; \mathrm{F}(2,237)=1.06, \mathrm{p}=.348\right)$ were not significantly different between the three companies. See appendix 2 for correlations between de dependent variables distributive justice and LMX.

Hypotheses 1, which states agency workers perceive less distributive justice concerning different aspects of HRM than permanent workers, can be confirmed. Agency workers perceive significantly less distributive justice concerning physical conditions, information, voice, participation, pay, development, and job characteristics than do permanent workers, even when controlled for job tenure (Table 2). The effect size of contract status is large, which means that $11-20 \%$ of the variance of distributed justice concerning different aspects of HRM is caused by whether the workers have a permanent or an agency contract even when controlled for job tenure. Agency workers perceive less distributive justice than permanent workers.

Table 2: Analyses of covariance between agency workers $(\mathrm{N}=109)$ and permanent workers $(\mathrm{N}=131)$ concerning distributive justice regarding different aspects of HRM, controlling for tenure

\begin{tabular}{lllcccccc}
\hline & \multicolumn{2}{c}{ M (SD) } & \multicolumn{3}{c}{ Contract relation } & \multicolumn{2}{c}{ Job tenure } \\
& agency & permanent & $\mathbf{n}^{\mathbf{2}}$ & $\mathbf{d f}$ & $\mathbf{F}$ & $\mathbf{n}^{\mathbf{2}}$ & $\mathbf{d f}$ & $\mathbf{F}$ \\
\hline Physical Conditions & $2.78(1.08)$ & $3.46(.90)$ & .112 & $(1,237)$ & $29.15^{* *}$ & .026 & $(1,237)$ & $6.34^{*}$ \\
Information & $2.89(.93)$ & $3.52(.75)$ & .150 & $(1,239)$ & $41.80^{* *}$ & .046 & $(1,239)$ & $11.54^{* *}$ \\
Voice & $2.77(.99)$ & $3.49(.79)$ & .144 & $(1,238)$ & $39.71^{* *}$ & .032 & $(1,238)$ & $7.79^{*}$ \\
Participation & $2.34(.99)$ & $3.32(.99)$ & .171 & $(1,239)$ & $49.01^{* *}$ & .023 & $(1,239)$ & $5.49^{*}$ \\
Pay & $2.44(1.06)$ & $3.46(.93)$ & .147 & $(1,239)$ & $41.16^{* *}$ & .007 & $(1,239)$ & $1.71(\mathrm{~ns})$ \\
Development & $2.43(.93)$ & $3.29(.79)$ & .204 & $(1,240)$ & $61.18^{* *}$ & .044 & $(1,240)$ & $10.93 * *$ \\
Job Characteristics & $2.85(.81)$ & $3.53(.70)$ & .178 & $(1,240)$ & $51.65^{* *}$ & .044 & $(1,240)$ & $10.95^{* *}$ \\
\hline
\end{tabular}

$* * \mathrm{p}<.01 ; * \mathrm{p} \leq .05$

Hypothesis 2, stating that Polish agency workers perceive less distributive justice concerning different aspects of HRM than Dutch agency workers, can only be partly confirmed (Table 3). We found significant differences between Dutch and Polish agency workers concerning physical conditions, pay, development, and job characteristics, controlling for job tenure. This means: Even when controlled for job tenure, when Polish agency workers compare themselves with permanent staff they perceive less distributive justice concerning physical conditions, pay, development, and job characteristics than when Dutch agency workers compare themselves with permanent staff.. The effect size of Dutch-Polish origin is small to medium, which means that $5-6.5 \%$ of the variance of distributed justice concerning different aspects of HRM is caused by the agency workers origin even when controlled for job tenure. Polish agency workers perceive less distributive justice than Dutch agency 
workers. However, in contrast to the effect of 'contract status' on distributive justice (see hypothesis 1) the effect of 'origin' is relatively small.

Table 3: Analyses of covariance between Dutch agency workers $(\mathrm{N}=65)$ and Polish agency workers $(\mathrm{N}=67)$ concerning distributive justice regarding different aspects of HRM, controlling for tenure

\begin{tabular}{lccccccccc}
\hline & \multicolumn{2}{c}{ M (SD) } & \multicolumn{3}{c}{ Origin Dutch-Polish } & \multicolumn{2}{c}{ Job tenure } \\
& Dutch & Polish & $\mathbf{\eta}^{2}$ & $\mathbf{d f}$ & $\mathbf{F}$ & $\mathbf{\eta}^{2}$ & $\mathbf{d f}$ & $\mathbf{F}$ \\
\hline Ph. Conditions & $2.95(.99)$ & $2.61(1.14)$ & .051 & $(1,130)$ & $6.90^{*}$ & .074 & $(1,130)$ & $10.30^{* *}$ \\
Information & $2.86(.89)$ & $2.92(.98)$ & .002 & $(1,130)$ & 0.219 & .077 & $(1,130)$ & $10.73^{* *}$ \\
Voice & $2.66(.97)$ & $2.88(1.00)$ & .004 & $(1,129)$ & .461 & .048 & $(1,129)$ & $6.35^{*}$ \\
Participation & $2.30(.88)$ & $2.39(1.08)$ & .000 & $(1,130)$ & .002 & .023 & $(1,130)$ & 2.95 \\
Pay & $2.65(.96)$ & $2.22(1.11)$ & .055 & $(1,130)$ & $7.45^{* *}$ & .021 & $(1,130)$ & 2.73 \\
Development & $2.62(.90)$ & $2.24(.92)$ & .065 & $(1,131)$ & $8.91 * *$ & .045 & $(1,131)$ & $6.14^{*}$ \\
Job Characteristics & $2.99(.80)$ & $2.85(.81)$ & .050 & $(1,131)$ & $6.848^{* *}$ & .061 & $(1,131)$ & $8.43^{* *}$ \\
\hline
\end{tabular}

$* * \mathrm{p}<.01 ; * \mathrm{p} \leq .05$

For correlations between the dependent distributive justice variables and LMX see Appendix 2. The mediator role of LMX in the relation between contract status and distributive justice as well as agency workers origin and distributive justice (hypothesis 3 ) is partly confirmed. As shown in Table 4, both dummies, which stand for contract status as well as agency workers origin, are significant in model 2 for physical conditions $\left(\beta_{\mathrm{D} 1}=.18, \mathrm{p}<\right.$ $\left..05 ; \beta_{\mathrm{D} 2}=.61, \mathrm{p}<.01\right)$, pay $\left(\beta_{\mathrm{D} 1}=.19, \mathrm{p}<.01 ; \beta_{\mathrm{D} 2}=.67, \mathrm{p}<.01\right)$, development $\left(\beta_{\mathrm{D} 1}=.21\right.$, $\left.\mathrm{p}<.01 ; \beta_{\mathrm{D} 2}=.79, \mathrm{p}<.01\right)$ and job characteristics $\left(\beta_{\mathrm{D} 1}=.18, \mathrm{p}<.01 ; \beta_{\mathrm{D} 2}=.73, \mathrm{p}<.01\right)$, and dummy 2 is also significant for information $\left(\beta_{\mathrm{D} 2}=.57, \mathrm{p}<.01\right)$, voice $\left(\beta_{\mathrm{D} 2}=.49, \mathrm{p}<\right.$ .01 ) and participation $\left(\beta_{\mathrm{D} 2}=.57, \mathrm{p}<.01\right)$. Dummy 1 (which represents the permanent workers) is not always significant because the factor 'contract status' explains differences (H1) in distributive justice more than agency workers origin does $(\mathrm{H} 2)$. Both dummies $\left(\beta_{\mathrm{D} 1}\right.$ $\left.=.4, \mathrm{p}<.10 ; \beta_{\mathrm{D} 2}=.59, \mathrm{p}<.01\right)$ are significantly related to the mediator LMX.

Table 4, model 3, also shows that LMX is positively related to all the distributive justice aspects (physical conditions $\beta=.41, \mathrm{p}<.01$; information $\beta=.40, \mathrm{p}<.01$; voice $\beta=.45, \mathrm{p}<.01$; participation $\beta=.45, \mathrm{p}<.01$; pay $\beta=.35, \mathrm{p}<.01$; development $\beta=.52, \mathrm{p}<.01$; and job characteristics $\beta=.60, \mathrm{p}<.01)$. In case LMX is a full mediator, the significant beta's in model 2 of the dummies have to disappear in model 3. This is not the case. Table 4 shows that LMX is a partial mediator because the path from the dummies to contract status is reduced in absolute size if LMX is considered into the equation, but it is still different from zero.

With the Sobel test we checked the significance of this partial mediation effect of LMX. It turns out it is significant for all distributive justice HRM aspects (physical conditions (Sobel test statistic $\mathrm{D}_{\mathrm{D} 1}=1.81, \mathrm{p}<.10$; Sobel test statistic $\mathrm{D}_{\mathrm{D} 2}=4.51, \mathrm{p}<.01$ ), information (Sobel test statistic $\left.\mathrm{D} 2_{\mathrm{D}}=4.45, \mathrm{p}<.01\right)$, voice $($ Sobel test statistic $\mathrm{D} 2=4.71, \mathrm{p}<.01$ ), participation (Sobel test statistic $\mathrm{D}_{2}=4.76, \mathrm{p}<.01$ ), pay (Sobel test statistic $\mathrm{D}_{\mathrm{D} 1}=4.25, \mathrm{p}<$

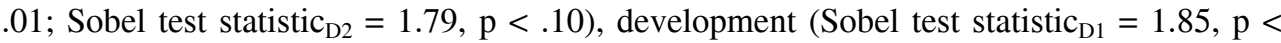
.10 ; Sobel test statistic $\mathrm{D}_{2}=5.13, \mathrm{p}<.01$ ), and job characteristics (Sobel test statistic $\mathrm{D}_{\mathrm{D} 1}=$ $1.85, \mathrm{p}<.10$; Sobel test statistic $\left.\mathrm{D}_{2}=5.30, \mathrm{p}<.01\right)$. 
Table 4: Results of employment relation, LMX and distributive justice by multiple regression

\begin{tabular}{|c|c|c|c|c|c|c|c|c|c|c|c|}
\hline variables & & Constant & Tenure & $D 1$ & $D 2$ & LMX & $D 1 * L M X$ & $D 1 * L M X$ & $\operatorname{Adj} R^{2}$ & $\Delta R^{2}$ & $F$ for $\Delta R^{2}$ \\
\hline Physical & 1 & $2.84^{* *}$ & $.12 \dagger$ & & & & & & .10 & .01 & $3.36 t$ \\
\hline \multirow[t]{3}{*}{ conditions } & 2 & $2.91 * *$ & $-.27 * *$ & $.18^{*}$ & $.61 * *$ & & & & .14 & .13 & $18.21^{* *}$ \\
\hline & 3 & $1.32^{\star *}$ & -.09 & $.13+$ & $.37^{* *}$ & $.41 * *$ & & & .29 & .15 & $50.17^{* *}$ \\
\hline & 4 & $.91 *$ & -.09 & $.39+$ & $.66^{* *}$ & $.54 * *$ & -.29 & -.35 & .29 & .01 & 1.18 \\
\hline \multirow[t]{4}{*}{ Information } & 1 & $3.01 * *$ & .11 & & & & & & .01 & .01 & 2.71 \\
\hline & 2 & $3.24 * *$ & $-.30 * *$ & .00 & $.57 * *$ & & & & .15 & .15 & $21.52^{* *}$ \\
\hline & 3 & $1.92 * *$ & -.13 & -.05 & $.33^{* *}$ & $.40 * *$ & & & .29 & .14 & $46.93^{* *}$ \\
\hline & 4 & $1.68^{* *}$ & -.13 & .01 & $.64^{* *}$ & $.49 * *$ & -.07 & -.36 & .29 & .01 & 1.07 \\
\hline \multirow[t]{4}{*}{ Voice } & 1 & $2.85^{* *}$ & $.15^{*}$ & & & & & & .02 & & $5.03^{*}$ \\
\hline & 2 & $3.16^{* *}$ & $-.23 * *$ & -.09 & $.49 * *$ & & & & .16 & & $21.09 * *$ \\
\hline & 3 & $1.57^{* *}$ & -.04 & $-.14^{\star}$ & $.22 *$ & $.45^{* *}$ & & & .34 & & $63.07 * *$ \\
\hline & 4 & $1.12^{* *}$ & -.03 & .23 & $.52 *$ & $.59 * *$ & $-.40 t$ & -.36 & .34 & & 1.89 \\
\hline \multirow[t]{4}{*}{ Participation } & 1 & $2.34^{* *}$ & $.22 * *$ & & & & & & .04 & .05 & $11.95^{* *}$ \\
\hline & 2 & $2.64^{* *}$ & $-.2 .33^{*}$ & -.01 & $.57 * *$ & & & & .20 & .17 & $24.58 * *$ \\
\hline & 3 & $.86^{* *}$ & -.01 & -.07 & $.31 * *$ & $.45^{* *}$ & & & .38 & .17 & $66.33^{* *}$ \\
\hline & 4 & .36 & -.05 & $.41^{*}$ & $.50 *$ & $.59 * *$ & $-.53 *$ & -.24 & .39 & .12 & $3.12^{*}$ \\
\hline \multirow[t]{4}{*}{ Pay } & 1 & $2.33^{* *}$ & $.27 * *$ & & & & & & .07 & .08 & $19.18^{* *}$ \\
\hline & 2 & $2.43^{* *}$ & $-.15 t$ & $.19 * *$ & $.67^{* *}$ & & & & .23 & .16 & $24.97 * *$ \\
\hline & 3 & $.99 * *$ & -.00 & $.14^{*}$ & $.46^{* *}$ & $.35 * *$ & & & .34 & .11 & $38.71 * *$ \\
\hline & 4 & .30 & .01 & $.69 * *$ & $.81 * *$ & $.54 * *$ & $-.60 * *$ & $-.43 t$ & .35 & .02 & $3.92^{*}$ \\
\hline \multirow[t]{4}{*}{ Development } & 1 & $2.48^{* *}$ & $.19 * *$ & & & & & & .03 & .04 & $8.64 * *$ \\
\hline & 2 & $2.59^{* *}$ & $-.32 * *$ & $.21 * *$ & $.79 * *$ & & & & .26 & .23 & $36.94^{* *}$ \\
\hline & 3 & $.76^{* *}$ & -.10 & $.14^{*}$ & $.48^{* *}$ & $.52 * *$ & & & .49 & .24 & 110.77 ** \\
\hline & 4 & $.69 *$ & -.10 & .23 & $.50 *$ & $.54 * *$ & -.50 & -.13 & .49 & .00 & .13 \\
\hline \multirow{4}{*}{$\begin{array}{l}\text { Job } \\
\text { characteristics }\end{array}$} & 1 & $2.92 * *$ & $.15^{*}$ & & & & & & .02 & .02 & $5.63^{*}$ \\
\hline & 2 & $3.02 * *$ & $-.32^{* *}$ & $.18 * *$ & $.73 * *$ & & & & .21 & .20 & $29.85^{* *}$ \\
\hline & 3 & $1.19 * *$ & -.06 & $.10 \dagger$ & $.37 * *$ & $.60 * *$ & & & .53 & .32 & 159.29 ** \\
\hline & 4 & $1.12^{* *}$ & -.06 & .02 & $.56^{* *}$ & $.63^{* *}$ & .08 & -.20 & .53 & .00 & 1.02 \\
\hline
\end{tabular}

$* * \mathrm{p}<.01 ; * \mathrm{p}<.05 ; \dagger \mathrm{p}<.10$

Table 4, model 4, displays the results of testing hypothesis 4 . We found a significant moderator effect of LMX for voice, participation and pay, partly confirming the hypothesis. The results are shown graphically in Figure 1. All three groups score higher on perceived distributive justice concerning voice, participation and pay when LMX is perceived as high instead of low. However, the Polish agency workers seem to benefit more from perceived high LMX than the other two groups (i.e., permanent staff and Dutch agency workers). The differences between Polish agency workers and permanent workers clearly disappear or become smaller in a high LMX situation. In contrast, the differences between Dutch agency workers and permanent workers in a high LMX situation remain. Moreover, it seems Polish agency workers tend to have higher scores than Dutch agency workers have in a high LMX situation. 

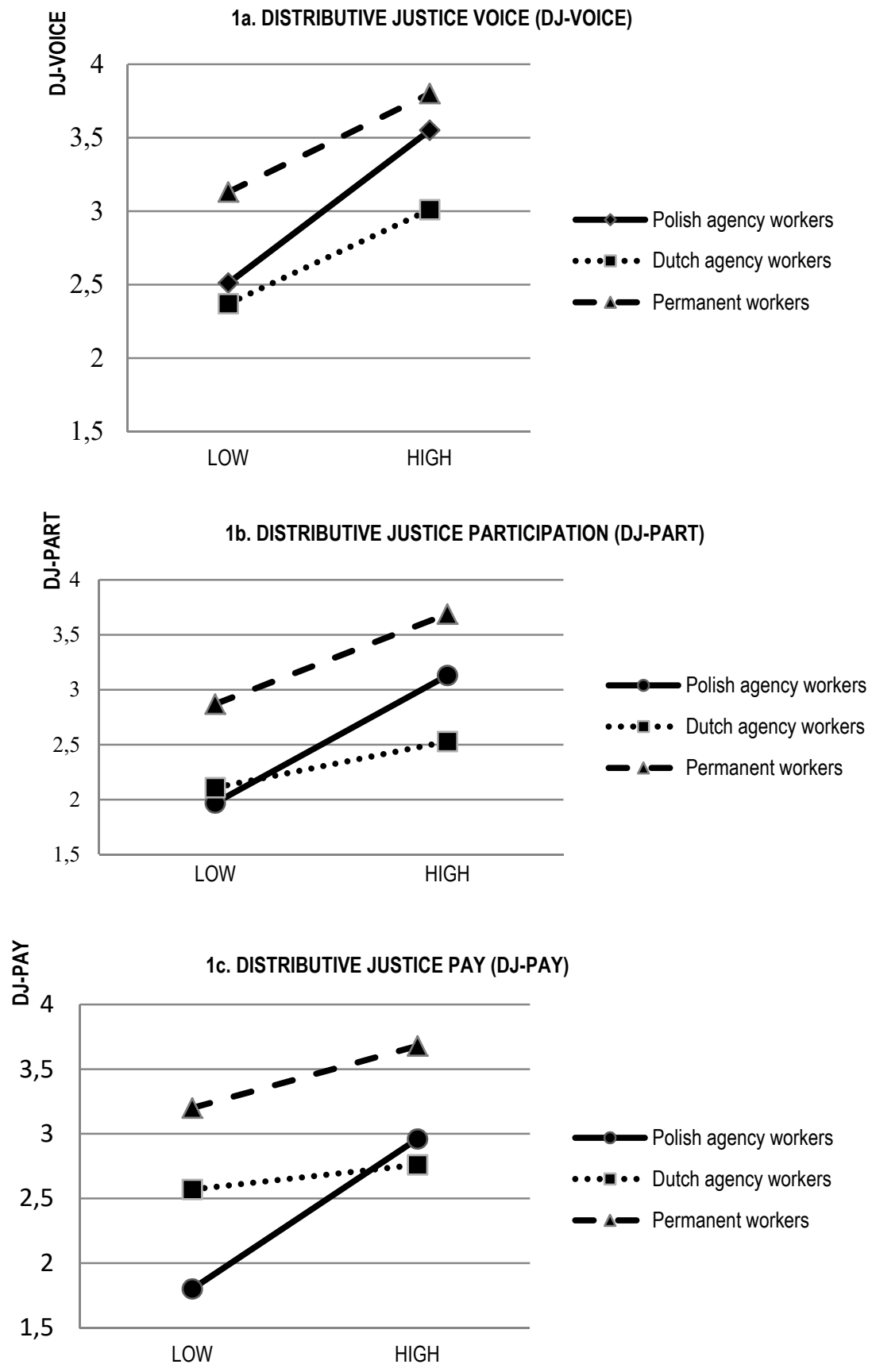

Figure $1 a, 1 b$ and $1 c$ : Interaction effect for perceived distributive justice concerning voice, participation and pay 


\section{Discussion}

Our results bolster previous evidence and assumptions (e.g. Brinkmann \& Nachtwey, 2014; Helfen et al., 2015; Nienhüser \& Matiaske, 2006): Agency workers perceive less distributive justice concerning pay, job content, physical working conditions, information, voice, direct participation, and development opportunities than permanent employees (confirmation of hypothesis 1). A deeper look into the data shows that when comparing themselves with permanent staff, Polish agency workers perceive less distributive justice concerning pay, job content, physical working conditions, and development opportunities than when Dutch agency workers compare themselves with permanent staff (confirmation of hypothesis 2). Nevertheless, hypothesis 2 could only be partly confirmed since Polish agency workers do not perceive less distributive justice concerning information, voice, and direct participation than local agency workers. Moreover, in contrast to the effect of 'contract status' on distributive justice the effect of 'origin' is relatively small. However, the effect of origin might is stronger for other work migrants. For example, Bulgarians seem to perceive more group discrimination than Polish people in the Netherlands. 66 percent of the Bulgarians perceive 'very frequently' group discrimination in contrast to 49 percent of the Polish people. Moreover, while 81 percent of the Polish people are satisfied with their life in the Netherlands, only 45 percent of the Bulgarians are (Gijsberts \& Lubbers, 2015).

It might is too easy pointing to 'purposely' discrimination as the explanation for Polish agency workers negative responses towards pay, job content, physical working conditions, and development opportunities. After all, several Dutch industries (i.e., food, horticulture and logistics) strongly have to depend on migrant workers (ABU, 2016) and therefore cannot permit themselves discrimination and, consequently, undesired worker attitudes and behaviour (see also the special issue of the Journal of Managerial Psychology on employment discrimination against immigrants; Dietz, 2010). What are alternative explanations? Perceived distributive injustice concerning pay can be the result of unfulfilled expectations. In the theoretical section (see the reasoning for hypothesis 2), we argued that work migrants might have higher expectations concerning monetary rewards than local agency workers and permanent staff: They may make higher sacrifices (for example, leaving their home country and family [temporarily]) and have higher living costs (for example, housing in the Netherlands and abroad) than their local counterparts. Referring to job content and physical working conditions, studies show that (initially) the occupational status after migration decreases. Researchers point to limited command of the migration countries language and a misfit between migrants education and labour market demands as reasons (e.g. Akresh, 2006; Chiswick et al., 2005). Finally, Polish agency workers perceived distributive injustice concerning development opportunities might be explained by a mismatch between their migrant country orientation and temp agencies as well as user companies assumptions. In contrast to what has been assumed for many years, many migrants from Central Europe and especially Poland perceive their stay in the Netherlands not as temporarily and purely income oriented, but wish to relocate permanently. This seems to be especially true for lower educated people and those with a family in the Netherlands. In general, 56 percent of the Polish people want to stay in the Netherlands (Gijsberts \& Lubbers, 2015). In other words: It is not only between group differences (i.e., local vs. foreign agency workers) that might 
be relevant, but also within group differences (e.g., foreign agency workers are a heterogeneous group).

Hypotheses 3 and 4 challenged research that found a direct relationship between contract status (here, agency workers vs. permanent employees) and unequal treatment (e.g. Brinkmann \& Nachtwey, 2014; Helfen et al., 2015; Nienhüser \& Matiaske, 2006). Based on empirical studies, we alternatively presumed Leader-Member Exchange (LMX; i.e., the quality of the relationship with the direct supervisor at the user firm as perceived by his/her followers) mediates and/or moderates these relationships. In other words, the contract status determines LMX and, consequently, distributive justice perceptions (hypothesis 3) and/or the contract status does not determine LMX (i.e., the relationship quality with the direct supervisor can be low or high for permanent employees and agency workers), but LMX determines distributive justice (hypothesis 4). Moreover, although this is not the first study that includes LMX in the context of temporary work (see Flickinger et al., 2016), to our knowledge this is the first study on LMX that takes migrant status into account (i.e. Dutch agency workers vs. Polish agency workers). Our results show that hypothesis 3 and 4 are complimentary. Although, a direct relationship between contract status and distributive justice perceptions remains when testing the mediator effect of LMX, contract status seems partly to determine perceived LMX and, consequently, perceived justice. Thus, the observation that agency workers in general (hypothesis 1) and specifically Polish agency workers (hypothesis 2), compared to permanent workers, perceive less justice, can be partly explained by the negative effect their contract status has on LMX (hypothesis 3).

However, the differences in perceived justice concerning voice, participation and pay between the groups (i.e., permanent staff, local agency workers, Polish agency workers) change when individual workers (i.e., independent of group membership) perceive highquality LMX (hypothesis 4). In this context, it is important to notice that in terms of distributive justice concerning pay, participation, and voice, the results show Polish agency workers seem to respond better to experienced high-quality LMX than do Dutch agency and permanent workers (see for possible explanations below). These findings challenge the outcomes Flickinger et al. (2016) found in their study among (mostly) highly qualified permanent staff and agency workers: For agency workers, the role of LMX in the relationship between job satisfaction and turnover intentions seems to be reduced.

Our results show that independent of the contract status or origin, a good relationship with the supervisor is better for perceived justice than a bad relationship (see also, for example, Andrews \& Kacmar, 2001; Lee, 2001; Piccolo et al., 2008; Scandura, 1999). Therefore, this study indirectly supports research that shows a positive influence of interactional justice (the social exchange between the individual and his or her supervisor refers to interactional justice; e.g. Cropanzano et al., 2002) on distributive justice (e.g. Colquitt et al., 2001). Moreover, agency workers can also develop a high-quality relationship with their direct supervisor. Thus, as stated in our theoretical framework, supervisors can have different relationships with each of their specific subordinates, independent of their contract status or origin. These findings show that assuming a direct relationship between contract status and consequences in general is misguided: many factors can interfere.

For the differences between Dutch and Polish workers concerning the influence of LMX, two reasons might be responsible. First, Polish workers may appreciate a good rela- 
tionship with their supervisor significantly more than Dutch workers do. After all, for them 'good treatment' or 'non-discrimination' in the Netherlands in general seems less obvious than for Dutch people (Gijsberts \& Lubbers, 2015). Second, Polish workers may meaningfully ascribe more power to their supervisor than Dutch workers do (Kolman et al., 2003). Given these assumed differences, future research should include relevant measures to detect these subtle yet effective factors.

\section{Practical implications}

Adequately meeting workers expectations is essential for desired attitudes and, consequently, behaviour (e.g. Bao Le et al., 2015; Chambel et al., 2016). Therefore, agencies as well as user firms are well advised to monitor the diverse preferences of agency workers in general and should not simply base their decision-making about 'what is appropriate HRM' on assumptions and abstract categories such as age, gender or origin. After all, inappropriate HRM as perceived by agency workers might result in undesired behaviour. As literature shows, for agencies and user firms alike it seems to be important to monitor the orientation of migrant workers towards the country of work: Do they want to stay or do they want to go? Our research shows that managers assumptions about this orientation was wrong (i.e., Polish workers do not want a permanent contract with the user firm): 71.6 percent of the Polish agency workers seem to prefer such a contract and research shows that the majority of Polish people (56\%) want to relocate to the Netherlands permanently.

Moreover, the results show that the relationship quality with the direct supervisor at the user firm seems decisive for agency and permanent workers justice perceptions. Thus, is it permissible to scapegoat supervisors for unfair treatment? Our answer is negative. In general, even when top management delegates operational HRM to direct supervisors, the former should communicate expectations concerning worker treatment to the line, and then monitor closely if and how supervisors act accordingly. Furthermore, agencies and user firms have a shared responsibility for the treatment of agency workers: Agencies 'deliver' the basic working conditions (i.e., pay and benefits); user firm's other aspects of HRM (e.g., physical and social working conditions, job content). Since the treatment offered by one party can cause spill-over effects for the other party in a positive or negative sense (e.g. Benson, 1998; Coyle-Shapiro et al., 2006; Liden et al., 2003; Van Breugel et al., 2005), agencies and user firms are well advised to continuously discuss their HRM in action, and if necessary correct each other on a timely basis.

\section{Limitations and future research directions}

As with all studies, this one also has shortcomings that should be addressed; not at least to overcome those in future research. For several reasons the transferability of the results is limited. The research was done in the Netherlands and encompasses only one sector (logistics), three companies, and (a limited number of) low-skilled workers. Therefore, transferring assumptions based on this study to other countries, sectors, companies, and worker groups should be done with caution. As explained before, even after implementing the EU's Agency Work Directive, space for differences in treatment can remain. Thus, additional country specific regulations as well as individual agencies and user firms can 'enrich' this 
space in a positive or negative sense. This raises the virtue of calling for crossnational and multiple case study research.

Referring to multiple case studies, in contrast to what previous evidence shows, our participating organisations tried to do their best to offer to all agency workers fair HRM. As such we can refer to them as 'best cases'. Getting insight into the other side of the 'extreme' continuum, into critical worst cases, would be an asset since these no doubt might acutely challenge our findings: For example, in organisations that really discriminate (certain) agency workers one might not find a moderator effect, but a full mediator effect of LMX. However, admittance to such organisations with common strategies is very difficult, and applying 'mainstream' methods may is impossible.

For several reasons, we are also critical on what and how we have measured. First, justice researchers routinely rightly emphasize the importance of including distributive, procedural, interpersonal, and informational justice (Colquitt, 2001; Colquitt et al., 2001). We only measured distributive justice perceptions and indirectly a form of interactional justice, namely LMX. Second, we mentioned before it is possible that differences in justice perceptions concerning HRM relate to different (pre-entry) expectations. Several scholars assume that this so-called psychological contract should be taken into account in research on justice perceptions (e.g. Cropanzano \& Prehar, 2001; Herriot et al., 1997) and in particular research on agency workers (Guest, 2004; McLean Parks et al., 1998; Rousseau, 1995). However, we did not measure workers expectations. Third, we only measured LMX among subordinates and therefore excluded another central party: the direct supervisor at the user firm. Moreover, and this has not been done yet, it would be advantageous to include the contact person at the agency to see whether or not, and if so to what degree, the quality of this relationship also influences agency workers' justice perceptions. Fourth, we controlled for several background variables including gender, age, contract preference (user firm contract) and tenure user firm. In contrast to tenure user firm, in this study age, gender and contract preference are no relevant covariates. However, these variables might play a role in different study settings and therefore should be included in future research. Research should also include education (level), orientation towards the migrant country (preference for permanent or temporary stay) and perceived own and group discrimination in general (i.e., outside the work context) Because all participants performed low skilled jobs, we did not measure education level. As mentioned before, the orientation towards the migrant country and perceived discrimination outside work might influence justice perceptions related to work. Finally, we asked the agency workers to compare themselves with permanent employees and permanent employees to compare themselves with agency workers concerning several aspects of distributive justice. We decided to determine the comparison group in the way we did, because the large amount of research on agency workers shows unequal treatment between agency workers and permanent staff. This can be seen as a serious limitation of the study. After all, we cannot be sure if these groups indeed are, from the viewpoint of the respondents, the most appropriate groups for comparison on issues of distributive justice. Moreover, comparative information about Polish agency workers' perceived justice vis-à-vis local agency workers and vice versa is missing, as well as insight into permanent workers' justice perceptions when comparing themselves with the two different groups of agency workers. Finally, this approach neglects the fact that agency workers are not a ho- 
mogenous group (e.g. De Cuyper et al., 2008; Guest, 2004). Therefore, future research should let the respondents decide with whom they wish to compare themselves.

\section{References}

ABU. (2016). Flexmigranten. Retrieved 01.10.2016, from https://www.abu.nl/themas/flexmigranten.

Adams, J. S. (1963). Towards an understanding of inequity. Journal of Abnormal and Social Psychology, 67, 422-436. https://doi.org/10.1037/h0040968

Adams, J. S. (1965). Inequity in social exchange. In: L. Berkowitz (ed.), Advances in experimental social psychology (Vol. 2) (pp. 267-299). New York: Academic Press. https://doi.org/10.1016/s00652601(08)60108-2

Akresh, I. R. (2006). Occupational Mobility Among Legal Immigrants to the United States. International Migration Review, 40, 854-884. https://doi.org/10.1111/j.1747-7379.2006.00046.x

Andrews, M. C., \& Kacmar, K. M. (2001). Discriminating among organizational politics, justice, and support. Journal of Organizational Behavior, 22, 347-366. https://doi.org/10.1002/job.92

Bao Le, T. T., Santos, G. G., \& Ferreira, A. P. (2015). Psychological contract breach and violation: The case of temporary workers in Vietnam. In: C. Machado (ed.) International Human Resources Manage-ment (pp. 91-108). Cham: Springer International Publishing.

Baron, R. M., \& Kenny, D. A. (1986).The moderator-mediator variable distinction in social psychologi-cal research: conceptual, strategic, and statistical considerations. Journal of Personality and Social Psy-chology, 51, 1173-1182. https://doi.org/10.1037/0022-3514.51.6.1173

Benson, J. (1998). Dual commitment: Contract workers in Australian manufacturing enterprises. Human Resource Management Journal, 35, 355-375. https://doi.org/10.1111/1467-6486.00097

Bickel, R. (2007). Multilevel analysis for applied research. It's Just Regression!. New York: The Guilford Press.

Brinkmann, U., \& Nachtwey, O. (2014). Prekäre Demokratie? Zu den Auswirkungen atypischer Beschäftigung auf betriebliche Mitbestimmung. Industrielle Beziehungen, 21, 78-98.

Chambel, M. J., Lorente, L., Carvalho, V., \& Martinez, I. M. (2016). Psychological contract profiles among permanent and temporary agency workers. Journal of Managerial Psychology, 31, 79-94. https://doi.org/10.1108/JMP-02-2014-0070

Chiswick, B. R., Lee, Y. L., \& Miller, P. W. (2005). A Longitudinal Analysis of Immigrant Occupational Mobility: A Test of the Immigrant Assimilation Hypothesis. International Migration Review, 39, 332-353. https://doi.org/10.1111/j.1747-7379.2005.tb00269.x

Cohen-Charash, Y., \& Spector, P. E. (2001). The role of justice in organizations: A meta-analysis. Organ-izational Behaviour and Human Decision Processes, 86, 278-321. https://doi.org/10.1006/obhd.2001.2958

Colquitt, J. A. (2001). On the dimensionality of organizational justice: a construct validation of a measure. Journal of Applied Psychology, 86, 386-400. https://doi.org/10.1037/0021-9010.86.3.386

Colquitt, J. A., Conlon, D. E., Wesson, M. J., Porter, C. O., \& Ng, K. Y. (2001). Justice at the millennium: A meta-analytic review of 25 years of organizational justice research. Journal of Applied Psy-chology, 86, 425-445. https://doi.org/10.1037/0021-9010.86.3.425

Connelly, C. E., \& Gallagher, D. G. (2004). Emerging trends in contingent work research. Journal of Management, 50, 959-983.

Coyle-Shapiro, J. A-M., Morrow, P. C., \& Kessler, I. (2006). Serving two organizations: Exploring the employment relationship of contracted employees. Human Resource Management, 45, 561583. https://doi.org/10.1002/hrm.20132

Cropanzano, R., \& Folger, R. (1991). Procedural justice and worker motivation. In: R. M. Steers \& L. W. Porter (eds.), Motivation and work behavior Vol. 5) (pp. 131-143). New York: McGraw-Hill. 
Cropanzano, R., \& Prehar, C.A. (2001). Emerging justice concerns in an era of changing psychological contracts. In: R. Cropanzano (ed.) Justice in the workplace (pp. 245-270). Mahwah: Lawrence Erl-baum Associates.

Cropanzano, R., Prehar, C. A., \& Chen, P. Y. (2002). Using social exchange theory to distinguish pro-cedural from interactional justice. Group Organization Management, 27, 324-351. https://doi.org/10.1177/1059601102027003002

Dansereau, F., Graen, G., \& Haga, W. (1975). A vertical dyad linkage approach to leadership within formal organizations: a longitudinal investigation of the role-making process. Organizational Behavior and Human Performance, 13, 46-78. https://doi.org/10.1016/0030-5073(75)90005-7

Daileyl, R. C., \& Kirk, D. J. (1992). Distributive and procedural justice as antecedents of job dissatisfac-tion and intent to turnover. Human Relations, 45, 305-317. https://doi.org/10.1177/001872679204500306

De Cuyper, N., Jong, J. De, Witte, H. De, Isaksson, K., Rigotti, T., \& Schalk, R. (2008). Literature review of theory and research on the psychological impact of temporary employment: Towards a conceptual model. International Journal of Management Reviews, 10, 25-51. https://doi.org/10.1111/j.1468-2370.2007.00221.x

Dietz, J. (2010). Introduction to the special issue on employment discrimination against immigrants. Journal of Managerial Psychology, 25, 104-112. https://doi.org/10.1108/02683941011019320

Dütsch, M., \& Struck, O. (2014). Atypische Beschäftigung und berufliche Qualifikationsrisiken im Erwerbsverlauf. Industrielle Beziehungen, 21, 58-77.

Flickinger, M., Allscher, M., \& Fielder, M. (2016). The mediating role of leader-member exchange: A study of job satisfaction and turnover intentions in temporary work. Human Resource Management Journal, 26, 46-62. https://doi.org/10.1111/1748-8583.12091

Garcia-Serrano, C. (2004). Temporary employment, working conditions and expected exits from firms. Labour, 18, 293-316. https://doi.org/10.1111/j.1121-7081.2004.00268.x

Gijsberts, M., \& Lubbers, M. (2015). Langer in Nederland. Den Haag: Sociaal en Cultureel Planbureau.

Giunchi, M., Chambel, M. J., \& Ghislieri, C. (2015). Contract moderation effects on temporary agency workers' affective organizational commitment and perceptions of support. Personnel Review, 44, 22- 38. https://doi.org/10.1108/PR-03-2014-0061

Giunchi, M., Emanuel, F., Chambel, M. J., \& Ghislieri, C. (2016). Job insecurity, workload and job exhaustion in temporary agency workers (TAWs): Gender differences. Career Development Interna-tional, 21, 3-18. https://doi.org/10.1108/CDI-07-2015-0103

Graen, G., \& Cashman, J. F. (1975). A role-making model of leadership in formal organizations: a developmental approach. In: Hunt, J.G. \& Larson, L.L. (eds.), Leadership Frontiers (pp. 143-65). Kent, Ohio: Kent State University Press.

Graen, G., Liden, R., \& Hoel, W. (1982a). Role of leadership in the employee withdrawal process. Journal of Applied Psychology, 67, 868-872. https://doi.org/10.1037/0021-9010.67.6.868

Graen, G., Novak, M., \& Sommerkamp, P. (1982b). The effects of leader-member exchange and job design on productivity and satisfaction: Testing a dual attachment model. Organizational Behavior and Human Performance, 30, 109-131. https://doi.org/10.1016/0030-5073(82)90236-7

Graen, G., \& Schiemann, W. (1978). Leader-member exchange: a vertical dyad linkage approach. Journal of Applied Psychology, 63, 206-212. https://doi.org/10.1037/0021-9010.63.2.206

Graen, G. B., \& Uhl-Bien, M. (1995). Development of leader-member exchange (LMX) theory of leadership over 25 years: applying a multi-level, multi-domain perspective. Leadership Quarterly, 6, 219-247. https://doi.org/10.1016/1048-9843(95)90036-5

Greenberg, J. (1990). Organizational justice: Yesterday, today, and tomorrow. Journal of Management, 16, 399-432. https://doi.org/10.1177/014920639001600208 
Guest, D. (2004). Flexible employment contracts, the psychological contract and employee outcomes: an analysis and review of the evidence. International Journal of Management Reviews, 5/6, 1-19. https://doi.org/10.1111/j.1460-8545.2004.00094.x

Helfen, M., Hense, A., \& Nicklich, M. (2015). Organisierte Ungleichheit in der Leiharbeit. Industrielle Beziehungen, 22, 282-304.

Herriot, P., Manning, W. E. G., \& Kidd, J. F. (1997). The content of the psychological contract. British Journal of Management, 8, 151-162. https://doi.org/10.1111/1467-8551.0047

Holm, K., Torkelson, E., \& Bäckström, M. (2016). New Types of Employment, New Ways to Be Uncivil? A Thematic Analysis of Temporary Agency Workers' Exposure to Workplace Incivility. Psy-chology, 7, 74-84. https://doi.org/10.4236/psych.2016.71009

Karregat, S., \& Steensma, H. (2005). Sociale rechtvaardigheid, psychologisch terugtrekgedrag en ziekte-verzuim. Gedrag \& Organisatie, 3, 139-155.

Keppel, G., \& Wickens, T. D. (2004). Design and Analysis: A Researcher's Handbook (4th Ed.). Upper Saddle River, N.J: Pearson Prentice Hall.

Kolman, L., Noorderhaven, N. G., Hofstede, G., \& Dienes, E. (2003). Cross-cultural differences in Central Europe. Journal of Managerial Psychology, 18, 76-88. https://doi.org/10.1108/02683940310459600

Lee, J. (2001). Leader-Member Exchange, perceived organizational justice, and cooperative communica-tion. Management Communication Quarterly, 14, 574-589. https://doi.org/10.1177/0893318901144002

Liden, R. C., \& Maslyn, J. M. (1998). Multidimensionality of leader-member exchange: an empirical assessment through scale development. Journal of Management, 24, 43-72. https://doi.org/10.1016/S0149-2063(99)80053-1 - https://doi.org/10.1177/014920639802400105

Liden, R. C., Wayne, S. J., Kraimer, M. L., \& Sparrowe, R. T. (2003). The dual commitments of contin-gent workers: an examination of contingents' commitment to the agency and the organization. Journal of Organizational Behavior, 24, 609-625. https://doi.org/10.1002/job.208

McDonald, D. J., \& Makin, P. J. (2000). The psychological contract, organizational commitment and job satisfaction of temporary staff. Leadership and Organizational Development Journal, 21, 8491. https://doi.org/10.1108/01437730010318174

McGinnity, F., \& M. Gijsberts (2016). A threat in the air? Perceptions of Group Discrimination in the first years after migration: comparing Polish Migrants in Germany, the Netherlands, the UK and Ireland. Ethnicities, 16, 290-315. https://doi.org/10.1177/1468796815616154

McLean Parks, J., Kidder, D. L., \& Gallagher, D. G. (1998). Fitting square pigs into round wholes: mapping the domain of contingent work arrangements onto the psychological contract. Journal of Organizational Behavior, 19, 697-730.

Meyer, J. P., Stanley, D. J., Herscovitch, L., \& Topolnytsky, L. (2002). Affective, continuance, and normative commitment to the organization: a meta-analysis of antecedents, correlates, and conse-quences. Journal of Vocational Behavior, 61, 20-52.

https://doi.org/10.1006/jvbe.2001.1842

Nienhüser, W., \& Matiaske, W. (2006). Effects of the 'principle of non-discrimination' on temporary agency work in 15 European countries. Industrial Relations Journal, 37, 64-77. https://doi.org/10.1111/j.1468-2338.2006.00390.x

Pearce, J. L. (1993). Toward an Organizational Behavior of Contract Laborers: Their Psychological Contract and Effect on Co-workers. Academy of Management Journal, 36, 1082-1096. https://doi.org/10.2307/256646

Perry, E. L., \& Kulik, C. T. (2008). The devolution of HR to the line: implications for perceptions of people management effectiveness. International Journal of Human Resource Management, 19, 262-273. https://doi.org/10.1080/09585190701799838 
Piccolo, R. F., Bardes, M., Mayer, D. M., \& Judge, T. A. (2008). Does high quality leader-member ex-change accentuate organizational injustice? European Journal of Work and Organizational Psychology, 17, 273-298. https://doi.org/10.1080/13594320701743517

Preacher, K. J., \& Hayes, A. F. (2004). SPSS and SAS procedures for estimating indirect effects in simple mediation models. Behavior Research Methods, Instruments, and Computers, 36, 717731. https://doi.org/10.3758/BF03206553

Purcell, J., \& Hutchinson, S. (2007). Front-line managers as agents in the HRM-performance causal chain: theory, analysis and evidence. Human Resource Management Journal, 17, 3-20. https://doi.org/10.1111/j.1748-8583.2007.00022.x

Rousseau, D. M. (1995). Psychological contracts in organizations: understanding written and unwritten agreements. Newbury Park, CA: Sage.

Scandura, T. A. (1999). Rethinking Leader-Member Exchange: An organizational justice perspective. Leadership Quarterly, 10, 25-40. https://doi.org/10.1016/S1048-9843(99)80007-1

Snijders, T. A. B., \& Bosker, R. J. (1999). Multilevel Analysis. An introduction to basic and advanced multilevel modeling. London: Sage Publications.

Thibaut, J., \& Walker, L. (1975). Procedural Justice: A Psychological Analysis. Hillsdale, NJ: Erlbaum.

Torka, N. (2003). Flexibel maar toch betrokken. Enschede: University of Twente Press.

Torka, N. \& Schyns, B. (2010). On equal job and co-worker commitment of agency workers and perma-nent employees: The role of HR practices. International Journal of Human Resource Management, 8, 1307-1322. https://doi.org/10.1080/09585192.2010.483858

Van Baars, W. (2014). Flexmigranten in Nederland - Onderzoek 2014. Retrieved 01.10.2016, from https://www.abu.nl/document/flexmigranten-in-nederland-2014.pdf

Van Breugel, G., Olffen, W., \& Olie, R. (2005). Temporary liaisons: The commitment of 'temps' towards their agencies. Journal of Management Studies, 42, 539-566. https://doi.org/10.1111/j.1467-6486.2005.00508.x

Vermeulen, H., Schellingerhout, R., Sijbers, R., \& van de Wetering, E. (2014). Uitzendmonitor 2014. Nijmegen: ITS, Radboud Universiteit Nijmegen.

Yukl, G., \& Fu, P. P. (1999). Determinants of delegation and consultation by managers. Journal of Organ-izational Behavior, 20, 219-232.

https://doi.org/10.1002/(SICI)1099-1379(199903)20:2<219::AID-JOB922>3.0.CO;2-8 


\title{
Appendix 1 Questionnaire items distributive justice and results principal com- ponent analysis (PCA)
}

\author{
Compared \\ to
}

(permanent employees respectively agency workers $) \ldots$ is/are $(1=$ much worse; to $5=$ much better $)$

\begin{tabular}{lllllllll}
\hline Variable & 1 & 2 & 3 & 4 & 5 & 6
\end{tabular}

\section{Pay}

My pay

My benefits (e.g., pension plan, travelling allowance)

\section{Job content}

The variety in my job $\quad 5.428$

$\begin{array}{ll}\text { The challenge in my job } & .874\end{array}$

The clarity about my tasks $\quad .744$

The freedom to plan my job and in performing my tasks $\quad .682$

The fit between my job and my personal skills $\quad .555$

The difficulty of my job $\quad .460$

The support for performing my tasks $\quad .368$

The appreciation I receive for my job effort $\quad .342$

My supervisors assessment concerning my job effort $\quad .316$

\section{Information}

Information I receive about (changes in) my job $\quad 2.446$

Information I receive about (changes in) my department $\quad .347$

Information I receive about (changes at) ... (name user firm)

\section{Voice}

My opportunities to raise voice about (changes in) my job

My opportunities to raise voice about (changes in) my department

firm)

\section{Direct participation}

My opportunities to co-decide about (changes in) my job

firm)

\section{Development opportunities}

My opportunities for training-on-the-job for my current job 
Appendix 2: Correlations between de dependent variables distributive justice and LMX

\begin{tabular}{|c|c|c|c|c|c|c|c|c|c|}
\hline & & $\begin{array}{c}\text { Ph. } \\
\text { Conditions }\end{array}$ & $\begin{array}{l}\text { Infor- } \\
\text { mation }\end{array}$ & Voice & $\begin{array}{l}\text { Participa- } \\
\text { tion }\end{array}$ & Pay & $\begin{array}{c}\text { Develop- } \\
\text { ment }\end{array}$ & $\begin{array}{c}\text { Job } \\
\text { Charac- } \\
\text { teristics }\end{array}$ & $\begin{array}{c}\text { Leader } \\
\text { Member } \\
\text { Exchange }\end{array}$ \\
\hline Physical & $\mathrm{R}$ & 1 & & & & & & & \\
\hline \multirow[t]{2}{*}{ Conditions } & $p$ & & & & & & & & \\
\hline & $N$ & 238 & & & & & & & \\
\hline \multirow[t]{3}{*}{ Information } & $\mathrm{R}$ & $.479^{* *}$ & 1 & & & & & & \\
\hline & $p$ & .000 & & & & & & & \\
\hline & $N$ & 237 & 240 & & & & & & \\
\hline \multirow[t]{3}{*}{ Voice } & $\mathrm{R}$ & $.538^{* *}$ & $.758^{* *}$ & 1 & & & & & \\
\hline & $p$ & .000 & .000 & & & & & & \\
\hline & $N$ & 236 & 239 & 239 & & & & & \\
\hline \multirow[t]{3}{*}{ Participation } & $\mathrm{R}$ & $.497^{* *}$ & $.624^{* *}$ & $.769^{* *}$ & 1 & & & & \\
\hline & $p$ & .000 & .000 & .000 & & & & & \\
\hline & $N$ & 237 & 240 & 239 & 240 & & & & \\
\hline \multirow[t]{3}{*}{ Pay } & $\mathrm{R}$ & $.471^{* *}$ & $.492^{* *}$ & $.540^{* *}$ & $.590^{* *}$ & 1 & & & \\
\hline & $p$ & .000 & .000 & .000 & .000 & & & & \\
\hline & $N$ & 237 & 240 & 239 & 240 & 240 & & & \\
\hline \multirow[t]{3}{*}{ Development } & $\mathrm{R}$ & $.608^{* *}$ & $.638^{* *}$ & $.653^{* *}$ & $.707^{* *}$ & $.632^{* *}$ & 1 & & \\
\hline & $p$ & .000 & .000 & .000 & .000 & .000 & & & \\
\hline & $N$ & 238 & 240 & 239 & 240 & 240 & 241 & & \\
\hline Job & $\mathrm{R}$ & $.650^{* *}$ & $.667^{* *}$ & $.718^{* *}$ & $.716^{* *}$ & $.629^{* *}$ & $.800^{* *}$ & 1 & \\
\hline \multirow[t]{2}{*}{ Characteristics } & $\mathrm{p}$ & .000 & .000 & .000 & .000 & .000 & .000 & & \\
\hline & $N$ & 238 & 240 & 239 & 240 & 240 & 241 & 241 & \\
\hline Leader Member & $R$ & $.488^{* *}$ & $.481^{\star *}$ & $.511^{\star *}$ & $.521^{\star *}$ & $.444^{* *}$ & $.619^{* *}$ & $.679^{* *}$ & 1 \\
\hline \multirow[t]{2}{*}{ Exchange } & $p$ & .000 & .000 & .000 & .000 & .000 & .000 & .000 & \\
\hline & $N$ & 237 & 238 & 237 & 238 & 238 & 239 & 239 & 239 \\
\hline
\end{tabular}

**. Correlation is significant at the 0.01 level (2-tailed). 


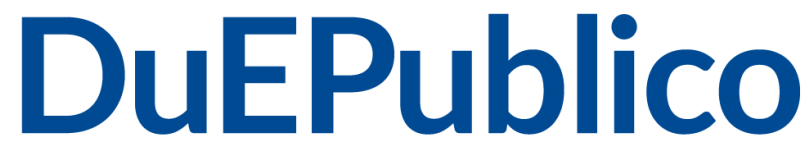

Duisburg-Essen Publications online

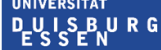

offen im Denken

Ub $\mid \begin{gathered}\text { universitäts } \\ \text { bibliothek }\end{gathered}$

This text is made available via DuEPublico, the institutional repository of the University of Duisburg-Essen. This version may eventually differ from another version distributed by a commercial publisher.

DOI: $\quad$ 10.3224/indbez.v24i1.06

URN: urn:nbn:de:hbz:464-20200717-130858-5 